\title{
Antibacterial Sensitivity and Detection of Virulence Associated Gene of Pasteurella multocida Isolated from Rabbits
}

\author{
Fatma M. Mohamed ${ }^{1}$, Marium F. Mansy ${ }^{2}$, Abd-El-Twab M. Abd-Al-Jwad ${ }^{3}$ and Ahmed K.Hassan ${ }^{4}$ \\ ${ }^{1,3}$ Poultry Diseases, Assiut Regional Laboratory, Animal Health Research Institute, Agricultural Research Center (ARC), Egypt. \\ ${ }^{2}$ Bacteriology, Assiut Regional Laboratory, Animal Health Research Institute, Agricultural Research Center (ARC), Egypt. \\ ${ }^{4}$ Department of Poultry diseases, Faculty of Veterinary Medicine, Assiut University, Egypt. \\ "Corresponding author's Email: fmmi66@yahoo.com; ORCID: 0000-0003-3393-4638
}

Received: 02 Feb. 2020

Accepted: 12 Mar. 2020

\begin{abstract}
The aim of the present work was to determine antibacterial sensitivity and resistance patterns of Pasteurella multocida isolated from rabbits in different farms of Assiut Governorate. Also, this study aimed to detect virulenceassociated gene (toxA) of Pasteurella multocida. A total of 40 freshly dead rabbits were used to collect samples from liver, lung and subcutaneous abscess. In addition, tracheal swab samples were collected from 20 diseased rabbits. Bacteriological examination revealed that Pasteurella spp. were isolated and phenotypically identified with an incidence rate of 55\% (33 out of 60 rabbits). Ten Pasteurella spp. isolates were randomly chosen for antibiotic sensitivity testing and molecular identification using PCR. Antibiotic sensitivity test was carried using standard disk diffusion method against 13 antibacterial drugs to determine antibacterial sensitivity and resistance patterns of Pasteurella isolates and revealed variable sensitivity and resistance to antibacterial drugs. Pasteurella multocida isolates were sensitive to wide variety of antibiotics (norfloxacin, enrofloxacin, ciprofloxacin, florfenicol, doxycycline, gentamycin, cephradine and cefoxitin). Three out of ten isolates were molecularly confirmed to be Pasteurella multocida and all of them demonstrated the presence of toxA virulence genes. In conclusion, the prevalence of Pasteurella infections in rabbits in Assiut Governorate was relatively high.
\end{abstract}

Key words: Antibacterial resístanse Pasteurella multocida, toxA gene, virulence genes.

\section{INTRODUCTION}

Rabbit pasteurellosis is a serious disease which causes a considerable economic loss in rabbit production units (Stelian et al., 2011). It is caused by Pasteurella multocida which may cause pneumonia and septicemia leading to death or local infections such as rhinitis, otitis media, conjunctivitis and abscesses (Deeb et al., 1990).

Pasteurella multocida is an important pathogen of the upper respiratory tract of various wild and domestic animals (Loubinoux et al., 1999). It is a small, Gramnegative, coccobacillus, non-motile, non-spore forming and facultative anaerobe which belongs to family Pasteurellaceae. Pasteurella multocida has been isolated from all ages of rabbits and colonized most commonly in the sinus, middle ear, trachea and lungs (Quinn et al., 1994).

Pasteurella multocida is the most common pathogen isolated from rabbits, its prevalence rate has been recorded to range from 7-100\% (Nakagawa et al., 1986; Deeb, et al., 1990; Kawamoto et al., 1990). It is considered an opportunist or secondary pathogen which can be found in the respiratory tract of both healthy and diseased animals. In rabbitries, it could emerge as a major pathogen that causes upper respiratory tract infections resulting in considerable economic losses (Deeb and DiGiacomo, 2000). Many researchers have distinguished various cases of non-infected, resistant and chronically infected animals or even healthy carriers (DiGiacomo, et al., 1983; Deeb, et al., 1990). Pasteurella multocida has been shown to adhere to the mucosal epithelium of the nasopharynx of rabbits by fimbriae (pili) which correlated to the virulence of the organism (Glorioso et al., 1982). A complex pathogenicity of $P$. multocida has been reported, and several virulence factors including hemagglutinins, fimbriae, lipopolysaccharides, hyaluronidase, iron regulated protein, capsule, iron acquisition proteins and a dermonecrotic toxin have been identified previously (Deeb and DiGiacomo, 2000). Previous reports could not detect toxA gene in P. multocida isolated from rabbits (Ferreira et al., 2012). In addition, other investigators mentioned that 
toxA gene is not commonly found in $P$. multocida strains isolated from rabbits (Ewers et al., 2006; García-Alvarez et al., 2015; Massacci et al., 2018).

Pasteurellosis in rabbits could be controlled through treatment with antibiotics and the slaughter of infected animals. Treating infected animals, however, only alleviates clinical signs and slows the progression of the disease, but it does not eliminate the infection (Deeb and DiGiacomo, 2000). Vaccination of P. multocida have been also reported using inactivated formalized $P$. multocida vaccine (Nassar et al., 2013). Methods of detection and diagnosis of $P$. multocida infections relied on microscopic detection of the pathogen via stained smears, isolation by culturing on selective media, then phenotypic or characterization serologically (Christensen and Bisgaard, 2010).

This study aimed to detect and identify P. multocida by phenotypic characterization and molecular identification in rabbits as well as to determine its antibacterial sensitivity and resistance patterns. In addition, this study investigated the occurrence of toxA, a gene associated with the virulence, in P. multocida.

\section{MATERIALS AND METHODS}

\section{Ethical approval}

The research protocol was reviewed and approved by Institutional Animal Care and use Committee (Vet CU20022020160).

\section{Sample collection}

A total of 40 recently dead rabbits with a previous respiratory manifestation (snuffling) were used to collect samples from liver, lung and subcutaneous abscesses. In addition, 20 diseased rabbits were used to collect tracheal swabs. All rabbits used ranged from 8 to 48 weeks old, and were obtained from different farms in Assuit Governorate, Egypt. Samples were collected under complete aseptic conditions in sterile tubes containing nutrient broth, transferred immediately to the lab in an icebox for bacteriological examination.

\section{Isolation of Pasteurella multocida}

The collected samples were inoculated into brain heart infusion broth (BHI) and incubated for 24 hours at $37^{\circ} \mathrm{C}$. Sub-culturing was carried out on sheep blood agar (5\%) then incubation for 24 hours at $37^{\circ} \mathrm{C}$. Growth was examined for typical P. multocida colonies.

\section{Phenotypic identification}

To confirm the presence of Pasteurella on suspected samples, Gram's stain was used for staining films from bacterial isolates for morphological characters and staining reaction as a first step for isolates identification and differentiation. In addition, biochemical reactions; including catalase, urease and indole tests and fermentation of sugars tests including dextrose, sucrose, maltose, dulcitol, arabinose, xylose, lactose, mannitol, galactose and salicin (Cruickshank et al., 1975) were used. Pasteurella isolates were preserved at $30 \%$ glycerol sterile solution (Biyashev et al., 2014).

\section{Antibacterial sensitivity and resistance patterns}

Sensitivity of Pasteurella isolates to antibacterial agents was determined using standard disk diffusion method. The criteria proposed by the National Committee for Clinical Laboratory Standards (CLSI, 2013) was used to determine susceptibility rates. The antibiotic discs (Oxoid) used in current study were: erythromycin $(15 \mu \mathrm{g})$, amoxicillin $(30 \mu \mathrm{g})$, cephradine $(30 \mu \mathrm{g})$, colistin $(10 \mu \mathrm{g})$, ciprofloxacin $(5 \mu \mathrm{g})$, enrofloxacin $(5 \mu \mathrm{g})$, cefoxitin $(30$ $\mu \mathrm{g})$, gentamicin $(10 \mu \mathrm{g})$, neomycin $(10 \mu \mathrm{g})$, streptomycin $(10 \mu \mathrm{g})$, florfenicol $(15 \mu \mathrm{g})$, doxycycline $(30 \mu \mathrm{g})$, and norfloxacin $(10 \mu \mathrm{g})$. Interpretation of results was performed according to Quinn et al. (1994) and Koneman et al. (1997).

\section{Multidrug resistant Index}

The multi-drug resistance index (MDRI) was determined for every isolate using the following equation according to Chandran et al. (2008):

$$
\text { MDR index }=\frac{\text { Number of antibiotics resisted }}{\text { Total number of antibiotics used }} \times 100
$$

When an isolate was resistant to more than three antibiotics, it was considered as multidrug resistant. Isolates were considered highly resistant when they had MDRI values of more than $0.2(20 \%)$.

\section{Molecular identification of Pasteurella isolates}

Ten randomly selected phenotypically identified Pasteurella isolates (five from dead rabbits and five from diseased rabbits) were subjected to molecular identification using PCR as following:

\section{DNA extraction}

DNA was extracted from the samples by using QIAamp DNA Mini kit (Qiagen, Germany, GmbH) 
according to manufacturer's recommendations. In brief, $200 \mu 1$ of the sample suspension were incubated with $10 \mu 1$ of proteinase $\mathrm{K}$ and $200 \mu 1$ lysis buffer at $56^{\circ} \mathrm{C}$ for 10 minutes. Then after, $200 \mu$ l of $100 \%$ ethanol were added to the lysate. The sample was then washed and centrifuged. Nucleic acid was eluted in $100 \mu$ l of elution buffer that was provided in the kit.

\section{Oligonucleotide primer}

The used primers (table 1) were supplied from Metabion (Germany).

\section{PCR amplification}

PCR primers were used in a $25-\mu 1$ reaction that contained $12.5 \mu 1$ of EmeraldAmp Max PCR Master Mix (Takara, Japan), $1 \mu \mathrm{l}$ from each primer of $20 \mathrm{pmol}$ concentration, $4.5 \mu 1$ of water, and $6 \mu 1$ of DNA template. The reaction was then carried out in an applied biosystem 2720 thermal cycler.

\section{Analysis of the PCR products}

By electrophoresis, the products of PCR were separated on $1 \%$ agarose gel (Applichem, Germany, $\mathrm{GmbH}$ ) at room temperature in 1xTBE buffer using gradients of $5 \mathrm{~V} / \mathrm{cm}$. $20 \mu \mathrm{l}$ of the products was loaded in each gel slot for gel analysis. Gelpilot 100bp DNA ladder (Qiagen, Germany, GmbH) was then used to determine the sizes of fragments. Photographing of the gel was done on a gel documentation system (Alpha Innotech, Biometra) and the data were then analyzed by computer software.

\section{Detection of toxA gene}

Ten samples of Pasteurella spp. which were previously identified, were subjected to PCR to detect toxA gene. DNA extraction from samples was carried out as previously mentioned. The used primers (Table 1) were supplied by Metabion (Germany). The PCR reaction was performed according to Townsend et al. (1998).

\section{RESULTS}

\section{Isolation rate of Pasteurella multocida}

Examination of individual diseased (20) and freshly dead (40) rabbits showed typical clinical signs and post mortem lesions of pasteurellosis. The results revealed 33
Pasteurella isolates were obtained from 60 examined rabbits with overall incidence of 55\%. The isolation of Pasteurella from lung, liver and subcutaneous abscesses samples from freshly dead rabbits revealed that 25 rabbits were positive for Pasteurella (62.5\%) while the examination of tracheal swab samples from diseased rabbits showed an isolation rate of $40 \%$ ( 8 out of 20 ).

\section{Phenotypic identification of Pasteurella isolates}

The growth of suspected $P$. multocida on brain heart infusion (BHI) agar, appeared as round gray large mucoid colonies. On 5\% sheep blood agar, colonies were nonhemolytic dew drop like. Gram stained slides of suspected colonies showed gram negative rods. The suspected $P$. multocida colonies were positive for catalase and indole, but negative for urease. However, sugar fermentation revealed that $P$. multocida colonies were positive with lactose, sucrose, dextrose, mannitol and galactose, but negative with dulcitol, salicin, arabinose, maltose and xylose.

\section{Antibacterial susceptibility and resistance patterns}

Results revealed that all Pasteurella spp. samples were sensitive to norfloxacin, enrofloxacin, ciprofloxacin, florfenicol, doxycycline, gentamycin, cephradine and cefoxitin. The isolates showed MDRI rang from (15.35\% to $42.86 \%$ ). The Sensitivity and resistance of P. multocida isolates to erythromycin, amoxicillin, colistin sulfate, neomycin and streptomycin were variable, results were summarized in table 2 .

\section{Molecular identification of Pasteurella multocida suspected isolates \\ Total ten samples were randomly chosen for} molecular identification using PCR. Three were confirmed as P. multocida and seven isolates were not confirmed (Figure 1).

\section{Detection of tox $A$ virulence gene}

Expression of toxA virulence gene was demonstrated in the three isolates that confirmed molecularly as $P$. multocida (Figure 2). 
Table 1. Primers sequences, target genes, amplicon sizes and cycling conditions

\begin{tabular}{|c|c|c|c|c|c|c|c|c|}
\hline \multirow{2}{*}{$\begin{array}{l}\text { Target } \\
\text { gene }\end{array}$} & \multirow{2}{*}{$\begin{array}{c}\text { Primers sequences } \\
\left(5^{\prime}-3^{\prime}\right)\end{array}$} & \multirow{2}{*}{$\begin{array}{c}\text { Amplified } \\
\text { segment } \\
\text { (base pair) }\end{array}$} & \multirow{2}{*}{$\begin{array}{c}\text { Primary } \\
\text { denaturation }\end{array}$} & \multicolumn{3}{|c|}{ Amplification ( 35 cycles) } & \multirow{2}{*}{$\begin{array}{c}\text { Final } \\
\text { extension }\end{array}$} & \multirow[b]{2}{*}{ Reference } \\
\hline & & & & $\begin{array}{c}\text { Secondary } \\
\text { denaturation }\end{array}$ & Annealing & Extension & & \\
\hline Kmtl & $\begin{array}{c}\text { F: ATC-CGC-TAT-TTA-CCC-AGT- } \\
\text { GG } \\
\text { R: GCT-GTA-AAC-GAA-CTC- } \\
\text { GCC-AC }\end{array}$ & 460 & $\begin{array}{l}94^{\circ} \mathrm{C} \\
5 \mathrm{~min}\end{array}$ & $\begin{array}{c}94^{\circ} \mathrm{C} \\
30 \mathrm{sec} .\end{array}$ & $\begin{array}{c}55^{\circ} \mathrm{C} \\
40 \mathrm{sec}\end{array}$ & $\begin{array}{l}72^{\circ} \mathrm{C} \\
45 \mathrm{sec} .\end{array}$ & $\begin{array}{c}72^{\circ} \mathrm{C} \\
10 \mathrm{~min}\end{array}$ & OIE (2012) \\
\hline $\operatorname{toxA}$ & F: CTTAGATGAGCGACAAGG & 864 & $\begin{array}{l}94^{\circ} \mathrm{C} \\
5 \mathrm{~min}\end{array}$ & $\begin{array}{l}94^{\circ} \mathrm{C} \\
30 \mathrm{sec} .\end{array}$ & $\begin{array}{l}55^{\circ} \mathrm{C} \\
40 \mathrm{sec}\end{array}$ & $\begin{array}{l}72^{\circ} \mathrm{C} \\
45 \mathrm{sec}\end{array}$ & $\begin{array}{l}72^{\circ} \mathrm{C} \\
10 \mathrm{~min}\end{array}$ & $\begin{array}{l}\text { Townsend } \\
\text { et al. (1998) }\end{array}$ \\
\hline
\end{tabular}

F: forward, R: reverse

Table 2. Antibacterial sensitivity test of Pasteurella multocida isolated from rabbits by disk diffusion method

\begin{tabular}{|c|c|c|c|c|c|c|c|c|c|c|c|c|c|c|}
\hline \multirow{2}{*}{ Isolate } & \multicolumn{13}{|c|}{ Results } & \multirow{2}{*}{ MDRI } \\
\hline & ER & $\mathbf{A X}$ & CT & $\mathbf{C P}$ & EN & $\mathrm{CO}$ & $\mathbf{C N}$ & NO & SP & FFC & DO & NR & CE & \\
\hline 1 & $\mathrm{R}$ & $\mathrm{R}$ & S & S & S & S & S & $\mathrm{R}$ & $\mathrm{R}$ & S & S & S & S & $30.07 \%$ \\
\hline 2 & S & $\mathrm{R}$ & $\mathrm{R}$ & $\mathrm{S}$ & $S$ & S & $S$ & $\mathrm{R}$ & $\mathrm{R}$ & S & S & $S$ & S & $30.07 \%$ \\
\hline 3 & $\mathrm{R}$ & S & $\mathrm{R}$ & S & S & S & S & S & $\mathrm{S}$ & S & S & S & S & $15.35 \%$ \\
\hline 4 & $S$ & $\mathrm{R}$ & $S$ & $\mathrm{~S}$ & $\mathrm{R}$ & $S$ & $S$ & $S$ & $\mathrm{R}$ & $\mathrm{R}$ & S & $S$ & $\mathrm{R}$ & $35.71 \%$ \\
\hline 5 & $\mathrm{R}$ & S & $\mathrm{R}$ & $\mathrm{S}$ & $S$ & $\mathrm{R}$ & $S$ & $\mathrm{R}$ & $S$ & S & $\mathrm{R}$ & S & $\mathrm{R}$ & $42.86 \%$ \\
\hline 6 & S & $\mathrm{R}$ & S & $\mathrm{S}$ & S & S & $\mathrm{R}$ & $\mathrm{R}$ & S & $\mathrm{R}$ & S & $S$ & S & $30.07 \%$ \\
\hline 7 & $\mathrm{R}$ & S & S & $\mathrm{R}$ & S & $\mathrm{R}$ & $S$ & S & S & S & $\mathrm{R}$ & $\mathrm{S}$ & S & $30.07 \%$ \\
\hline 8 & $\mathrm{R}$ & $\mathrm{R}$ & $\mathrm{R}$ & $\mathrm{S}$ & S & S & $S$ & $\mathrm{R}$ & $S$ & $S$ & S & $\mathrm{R}$ & S & $35.71 \%$ \\
\hline 9 & $\mathrm{R}$ & S & $S$ & $\mathrm{R}$ & $S$ & $S$ & S & $\mathrm{R}$ & S & S & S & $\mathrm{S}$ & S & $15.35 \%$ \\
\hline 10 & S & $\mathrm{R}$ & $\mathrm{R}$ & $\mathrm{S}$ & $\mathrm{R}$ & $S$ & $\mathrm{R}$ & S & S & $\mathrm{R}$ & S & $\mathrm{S}$ & S & $35.71 \%$ \\
\hline
\end{tabular}

ER: erythromycin, AX: amoxicilline, CT: colstine sulfate, CP: ciprofloxacin, EN: enrofloxacin, CO: cefoxitin, CN: gentamycine, NO: neomycine, SP: sterptomycine, FFC: florfenicol, DO: doxycycline, NR: norfloxacin, CE: cephradine, MDRI: multi-drug resistance index. S: sensitive, R: resistance.

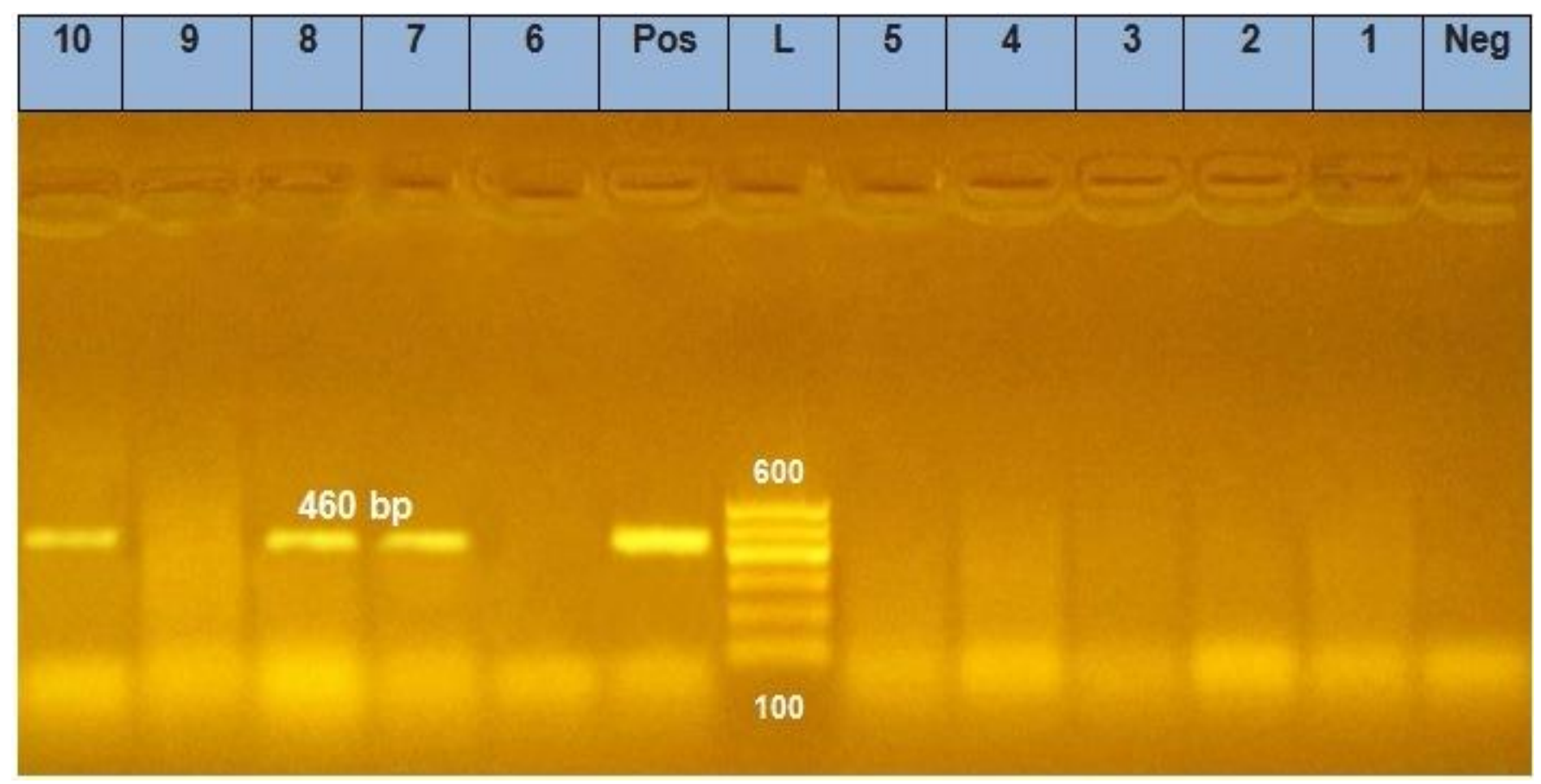

Figure 1. Agarose gel electrophoresis showing amplification of $460 \mathrm{bp}$ fragments specific for Pasteurella multocida of 10 samples isolated from rabbits. Lanes 1-6 and 9 are negative, Lane 7, 8 and 10 are positive samples for kmt gene. L: 100bp ladder (100-1000bp). Pos: positive control, Neg: negative control 


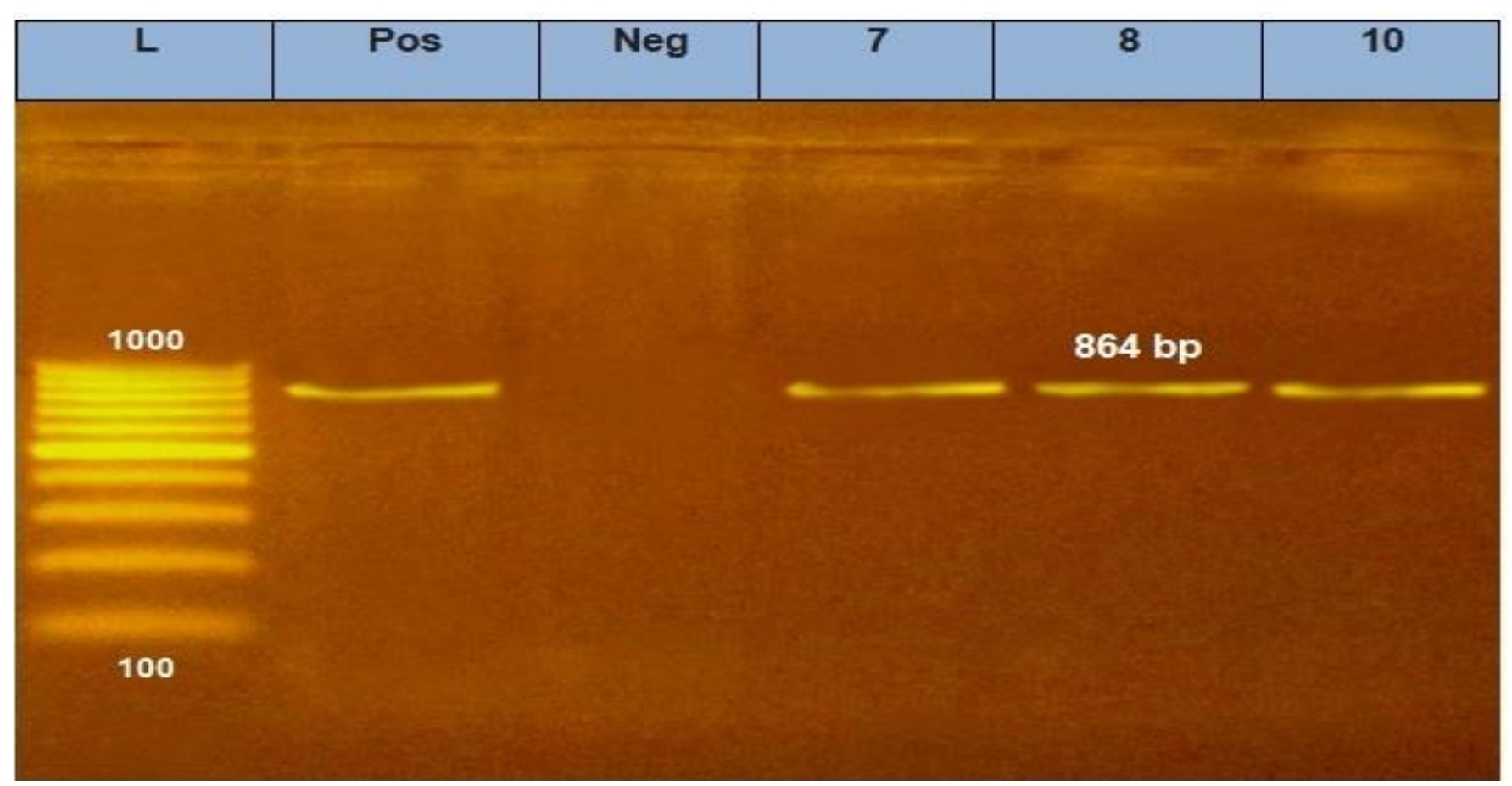

Figure 2. PCR results for 864bp toxA gene of Pasteurella mutocida showing positive amplification of the gene in tested samples isolated from rabbits. Lanes 7, 8, and 10 are positive samples for toxA gene, Pos: positive control, Neg: negative control. L: 100bp ladder (100-1000bp).

\section{DISCUSSION}

The relatively high prevalence rate of Pasteurella isolation in the current study suggests that it is probably an important pathogen causing high mortality in rabbits. Previous studies revealed variable incidences of $P$. multocida isolation (Lee et al., 1990; Takashima et al., 2001; Stelian et al., 2011). Sanchez et al. (2004) isolated P. multocida from clinically healthy animals with a prevalence of $20-90 \%$. However, low values of isolation incidences were also previously reported for $P$. multocida from liver, lungs, spleen, heart-blood and nasal swabs of rabbits with an incidence ranging from $18.75 \%$ to $35.00 \%$ (Mazed et al., 2013). Lower values of prevalence (3.4\% to 9.4\%) have been recorded in diseased rabbits by Asran et al. (2016). This discrepancy in prevalence rates of $P$. multocida could be attributed to method of detection employed or the locality in which the study was done.

Antimicrobial resistance test for 10 randomly selected Pasteurella isolates reveled that most of them showed multidrug resistant to more than two antibiotics with MDRI ranged from $15.35 \%$ to $42.86 \%$. Ferreira et al. (2012) investigated the antimicrobial sensitivity of $P$. multocida isolated from rabbits in Brazil and found that $47.8 \%$ of the strains were resistant to at least one of the tested drugs. However, in the current investigation, resistance was common against erythromycin, amoxicillin, colistin sulfate, neomycin and streptomycin. Unlikely, Tang et al. (2009) and Ferreira et al. (2012) reported that the high resistance of the isolates was against sulfonamides and cotrimoxazole. They reported that increased resistance of $P$. multocida against antimicrobials could be attributed to the irresponsible use, overuse, and misuse of antibiotics in rabbitaries.

Molecular identification is the basic method for identifying of $P$. multocida strains. Due to their great discriminatory power, DNA-based identification method has been established as an effective method in characterization of P. multocida (Blackall and Miflin, 2000). Using PCR as method for characterization, the current results showed that, three out of ten phenotypically identified Pasteurella isolates were confirmed as $P$. multocida (30\%). Similar findings have been obtained by Mazed et al. (2013), where the molecular detection by real-time PCR of $P$. multocida revealed its occurrence in diseased rabbit samples with an incidence of $29.5 \%$.

Therapy by using antimicrobial is one of the preliminary control measures to reduce morbidity and mortality resulting from $P$. multocida infections in rabbit and antibiotics are still the first choice to prevent and control P. multocida infections (Kehrenberg et al., 2001). However, the improper and misuse of antibiotics promotes 
the development of drug resistance (Percy et al., 1984; Kehrenberg et al., 2001; Oh et al., 2019). P. multocida isolates, in the present study, were sensitive to wide variety of antibiotics (norfloxacin, enrofloxacin, ciprofloxacin, florfenicol, doxycycline, gentamycin, cephradine and cefoxitin). However, sensitivity and resistance of $P$. multocida isolates to erythromycin, amoxicillin, colistin sulfate, neomycin and streptomycin were variable. These findings simulate previous reports that the most effective antibiotics against $P$. multocida are cephalosporins, florfenicol, tetracyclines, and fluoroquinolones (Salmon et al., 1995; Kehrenberg et al., 2001; Yoshimura et al., 2001; Ferreira et al., 2012).

The toxA genes is a virulence gene used for detection of the P. multocida pathogenicity (Furian et al., 2013). In consistence with Ahmed et al. (2016), who could detect toxA gene from rabbit $P$. multocida isolates in Egypt, the current investigation revealed the expression of toxA virulence gene of $P$. multocida in 3 out of 10 isolates. Unlikely, Ferreira et al. (2012) could not detect toxA gene in a study that performed on 46 P. multocida isolates with 0 percentage of presence of toxA gene. In addition, some other reports stated that this gene was uncommonly found in strains of $P$. multocida isolated from rabbits (Ewers et al., 2006; García-Alvarez et al., 2015; Massacci et al., 2018). ToxA gene has been reported to differentiate nontoxinogenic from toxinogenic strains of $P$. multocida (Lichtensteiger et al., 1996).

\section{DECLARATIONS}

\section{Acknowledgments}

The authors would like to thank the staff members in Assiut Regional Laboratory, Animal Health Research Institute, Agricultural research Center and in the Department of Poultry and Rabbit Diseases, Faculty of Veterinary medicine, Assiut University for offering facilities in processing the materials used in this study.

\section{Authors' contributions}

Fatma M Mohamed conceived the idea and planned the study. Fatma M Mohamed, Marium F. Mansy and Ahmed K. Hassan participated in the collection of samples, isolation and identification of $P$. multocida. Fatma M Mohamed and A. K. Hassan wrote the manuscript. A M Abd-Al-Jwad revised the manuscript.

\section{Competing interests}

The authors declare no conflict of interests.

\section{REFERENCES}

Ahmed S, Abdel-Salam MS, Hafez SS and Nemr W (2016). Molecular characterization of Pasteurella multocida isolated from Rrabbit in Egypt. American Journal of Biochemistry and Molecular Biology, 6: 53-59. DOI: https://doi.org/10.3923/ajbmb.2016.53.59

Asran EA, Khalil SA and Hegazy AHM (2016). Identification and Molecular Analysis of Pasteurella multocida Isolated from Rabbits. Alexandria Journal of Veterinary Sciences 2016, Jan. 48 (1): 34-41. DOI: https://doi.org/10.5455/ajvs. 187808

Biyashev KB, Kirkimbayeva Zh S, Maulanov AZ, Biyashev B, Makbuz AZh and Kuzembekova GB (2014). Pasteurellosis as the Most Common Infection Affecting the Respiratory System of Calves in Southern Kazakhstan. Global Veterinaria, 12 (6): 829-834. DOI: https://doi.org/10.5829/idosi.gv.2014.12.06.83242

Blackall PJ and Miflin JK (2000). Identification and typing of Pasteurella multocida: a review. Avian Pathology, 29, 271-287. DOI: https://doi.org/10.1080/03079450050118395

Chandran A, Hatha AA, Varghese S and Sheeia KM (2008). Prevalence of multiple drug resistant Escherichia coli serotypes in a tropical estuary, India. Microbes and Environment, 23(2):153-158. DOI: https://doi.org/10.1264/jsme2.23.153

Christensen H and Bisgaard M (2010). Molecular classification and its impact on diagnostics and understanding the phylogeny and epidemiology of selected members of Pasteurellaceae of veterinary importance. Berliner und Münchener Tierärztliche Wochenschrift, 123: 20-30. DOI: https://doi.org/10.2376/0005-9366-123-20

CLSI (2013). Performance Standards for Antimicrobial Susceptibility Testing; Twenty-Third Informational Supplement. CLSI document M100-S23. Wayne, PA: Clinical and Laboratory Standards Institute. Available

"https://www.facm.ucl.ac.be/intranet/CLSI/CLSI-M100S23susceptibility-testing-2013-no-protection.pdf"

Cruickshank R, Duduid JP, Marmion BP and Swain RHA (1975). Medical microbiology. 12 ${ }^{\text {th }}$ Ed. Vol. 11, Churchill Livingestone, Edinburgh, London and New York, pp. 587.

Deeb BJ and DiGiacomo RF (2000). Respiratory diseases of rabbits. Veterinary Clinics of North America: Exotic Animal Practice, 3 (2): 465-480. DOI: https://doi.org/10.1016/s1094-9194(17)30082-8

Deeb BJ, DiGiacomo RF, Bernard BL and Silbernagel SM (1990). Pasteurella multocida and Bordetella bronchiseptica infections in rabbits. Journal of Clinical Microbiology, 28:70-75. Available at: "https://www.ncbi.nlm.nih.gov/pmc/articles/PMC269539/"

DiGiacomo RF, Garlinghouse LE, Jr and Van Hoosier GL Jr (1983). Natural history of infection with Pasteurella multocida in rabbits. Journal of American Veterinary Medical Association, 183: 1172$1175 . \quad$ Available at: "https://www.ncbi.nlm.nih.gov/pubmed/6643228

Ewers C, Lübke-Becker A, Bethe A, Kiebling S, Filter M and Wieler LH (2006). Virulence genotype of Pasteurella multocida strains isolated from different hosts with various disease status. Veterinary Microbiology, 114: 304-17. DOI: https://doi.org/10.1016/j.vetmic.2005.12.012

Ferreira TSP, Felizardo MR, de Gobbi DDS, Gomes CR, Filsner PHdeLN, Moreno M, Paixao R, Pereira JdeJ and Moreno AM (2012). Virulence Genes and Antimicrobial Resistance Profiles of Pasteurella multocida Strains Isolated from Rabbits in Brazil. The Scientific World Journal, 2012, Article ID 685028, 6 pages DOI: https://doi.org/10.1100/2012/685028

Furian TQ, Borges KA, Rocha SLS, Rodrigues EE, do Nascimento VP, Salle CTP and Moraes HLS (2013). Detection of virulenceassociated genes of Pasteurella multocida isolated from cases of fowl cholera by multiplex-PCR. Pesquisa Veterinaria Brasileira, 33: 177-182. DOI: https://doi.org/10.1590/S0100-736X2013000200007

García-Alvarez A, Chaves F, Fernández A, Sanz C, Borobia M and Cid D (2015). An ST11 clone of Pasteurella multocida, widely spread 
among farmed rabbits in the Iberian Peninsula, demonstrates respiratory niche association. Infection Genetics and Evolution, 34:81-7. DOI: https://doi.org/10.1016/j.meegid.2015.07.018

Glorioso JC, Jones GW, Rush HG, Pentler LJ, Darif CA and Coward JE (1982). Adhesion of type A Pasteurella multocida to rabbit pharyngeal cells and its possible role in rabbit respiratory tract infections. Infection and Immunity, 35:1103-1109. Available at: "https://www.ncbi.nlm.nih.gov/pmc/articles/PMC351160/pdf/iai00 155-0355.pdf

Kawamoto E, Sawada T and Maruyama T (1990). Prevalence and characterization of Pasteurella multocida in rabbits and their environment in Japan. The Japanese Journal of Veterinary Science, 52:915-921. DOI: https:// 10.1292/jvms1939.52.915

Kehrenberg C, Schulze-Tanzil G, Martel JL, Chaslus-Dancla E and Schwarz S (2001). Antimicrobial resistance in Pasteurella and Mannheimia: epidemiology and genetic basis. Veterinary Research, 32: 323-39. DOI: https://doi.org/10.1051/vetres:2001128

Lee MD, Glisson JR and Wooley RE (1990). Characterization of Pasteurella multocida mutants of low virulence. Avian Diseases, 34: 958-963. DOI: https://doi.org/10.2307/1591389

Lichtensteiger CA, Steenbergen SM, Lee RM, Polson DD and Vimr ER (1996). Direct PCR analysis for toxigenic Pasteurella multocida. Journal of Clinical Microbiology, 34: 3035-3039. Available at: "https://www.ncbi.nlm.nih.gov/pmc/articles/PMC229455/pdf/3430 35.pdf

Loubinoux J, Lozniewski A, Lion C, Garin D, Weber M and Le Faou AE (1999). Value of enterobacterial repetitive intergenic consensus PCR for study of Pasteurella multocida strains isolated from mouths of dogs. Journal of Clinical Microbiology, 37: 2488- 2492. Available at: "https://www.ncbi.nlm.nih.gov/pmc/articles/PMC85264/pdf/jm002 488.pdf

Massacci FR, Maqistrali CF, Cucco L, Curcio L, Bano L, Manqili P, Scoccia E, Bisqaard M, Aalbæk B and Christensen H (2018). Characterization of Pasteurella multocida involved in rabbit infections. Veterinary Microbiology, 213:66-72. DOI: https://doi.org/10.1016/j.vetmic.2017.11.023

Mazed IM, Sharaf EM, Zakary EM and Atwa E (2013). Comparison between traditional methods and real time PCR for diagnosis of Pasteurella multocida from diseased rabbits. Benha Veterinary Medical Journal, 24 (1): 12-18. Available at: "http://www.bvmj.bu.edu.eg/issues/24-1/2.pdf

Nakagawa M, Nakayama K, Saito M, Takayama S and Watarai S (1986). Bacteriological and serological studies on Pasteurella multocida infection in rabbits. Jikken Dobutsu, 35: 463-469. DOI: https://doi.org/10.1538/expanim1978.35.4_463

Nassar SA, Mohamed AH, Soufy H and Nasr SM (2013). Protective effect of Egyptian propolis against rabbit pasteurellosis. BioMed Research International Volume 2013, Article ID: 163724, 9 pages. DOI: https://doi.org/10.1155/2013/163724

Oh YH, Moon DC, Lee YJ, Hyun BH and Lim SK (2019). Genetic and phenotypic characterization of tetracycline-resistant Pasteurella multocida isolated from pigs. Veterinary Microbiology, 233: 159163. DOI: https://doi.org/10.1016/j.vetmic.2019.05.001

OIE (2012). Manual of Diagnostic Tests and Vaccines for Terrestrial Animals (mammals, birds and bees). $7^{\text {th }}$ edition, Chapter 2.4.12, Haemorrhagic Septicaemia, rue de Prony, 75017 Paris, France, pp. 739-751.

Percy DH, Prescott JF and Bhasin JL (1984). Characterization of Pasteurella multocida isolated from rabbits in Canada. Canadian Journal of Comparative Medicine, 48:162-165. Available at: "https://www.ncbi.nlm.nih.gov/pmc/articles/PMC1236030/pdf/com pmed00006-0040.pdf

Quinn PJ, Carter ME, Markey B and Carter GR (1994). Pasteurella species. In: Clinical Veterinary Microbiology. Wolfe Publishing, Mosby - Year Book Europe Limited, London, pp 254-258.

Salmon SA, Watts JL, Case CA, Hoffman LJ, Wegener HC, and Yancey Jr RJ (1995). Comparison of MICs of ceftiofur and other antimicrobial agents against bacterial pathogens of swine from the United States, Canada, and Denmark. Journal of Clinical Microbiology, 33 (9): 2435-2444. Available at: "https://www.ncbi.nlm.nih.gov/pmc/articles/PMC228432/pdf/3324 35.pdf

Sanchez S, Mizan, S, Quist C, Schroder P, Juneau M, Dawe D, Ritchie B and Lee MD (2004). Serological response to Pasteurella multocida $\mathrm{NanH}$ sialidase in persistently colonized rabbits. Clinical and Diagnostic Laboratory Immunology, 11: 825-834. DOI: https:// 10.1128/CDLI.11.5.825-834.2004

Stelian B, Ivava S, Zaulet M, Otelea AR, Rotaru E, Judith I and Danes D (2011). Molecular epidemiology investigations in 8 Romanian outbreaks of rabbit pasteurellosis by Pulsed-Field gel electrophoresis. Romanian Biotechnology Letters, 16: 5841-5849 Available "https://www.rombio.eu/rbl1vol16/2\%20Baraitareanu.pdf

Takashima H, Sakai H, Yanai T and Masegi T (2001). Detection of antibodies against Pasteurella multocida using immunohistochemical staining in an outbreak of rabbit pasteurellosis. Journal of Veterinary Medical Science, 63: 171-174. DOI: https://doi.org/10.1292/jvms.63.171

Tang X, Zhao Z, Hu J, Wu B, Cai X, He Q and Chen H (2009). Isolation, antimicrobial resistance, and virulence genes of Pasteurella multocida strains from swine in China. Journal of Clinical $\begin{array}{llll}\text { Microbiology, } & 47 & \text { (4): } & 951-958 .\end{array}$ https://doi.org/10.1128/JCM.02029-08

Townsend KM, Frost AJ, Lee CW, Papadimitriou JM and Dawkins HJS (1998). Development of PCR Assays for Species- and TypeSpecific Identification of Pasteurella multocida Isolates. Journal of Clinical Microbiology, 36 (4): 1096-1110. Available at: "https://www.ncbi.nlm.nih.gov/pmc/articles/PMC104696/pdf/jm00 1096.pdf.

Yoshimura H, Ishimaru M, Endoh YS, and Kojima A (2001). Antimicrobial susceptibility of Pasteurella multocida isolated from cattle and pigs. Journal of Veterinary Medicine, 48 (7): 555-560. DOI: https://doi.org/10.1046/j.1439-0450.2001.00468.x 